\title{
O STUDIACH KULTUROWYCH NAD KRAJOBRAZEM I STUDIACH NAD PAMIĘCIAZ, A TAKŻE O TYM, CZEGO NAS (NIE) NAUCZYŁA HISTORIA ŚRODOWISKOWA
}

\author{
Maegorzata PraczyK ${ }^{1}$ \\ (Uniwersytet im. Adama Mickiewicza)
}

Karolina Ćwiek-Rogalska. Zapamiętane w krajobrazie. Krajobraz kulturowy czesko-niemieckiego pogranicza w czasach przemian. Warszawa: Wydawnictwo Naukowe Scholar, 2017. 215 S.

Interesująca i godna uwagi książka Karoliny Ćwiek-Rogalskiej wpisuje się w ugruntowaną już, także w Polsce, tradycję badań nad krajobrazem kulturowym (m.in. Frydryczak; Angutek). Autorka zdecydowała się na mikroperspektywę (Ćwiek-Rogalska 13), prowadząc badania nad przemianami krajobrazu kulturowego na czesko-niemieckim pograniczu, a konkretnie obrała jako przedmiot swoich obserwacji jedną gminę, Dolní Žandov, począwszy od 1918 roku aż po czasy współczesne.

Ćwiek-Rogalska jest młodą badaczką, która określa się mianem kulturoznawczyni, bohemistki i etnolożki i swoją ścieżką naukową podąża już z wyraźnymi sukcesami. Jest laureatką I edycji diamentowego grantu, w ramach którego realizowała projekt "Niezamierzone pomniki. Recepcja miejsc związanych z kulturą niemiecką w czeskich Sudetach na przykładzie gminy Dolní Žandov". W ramach tego projektu prowadziła ona między innymi badania w Žandovie, które legły u podstawy jej dy-

1 E-mail: praczyk@amu.edu.pl 
sertacji doktorskiej pt. „Przemiany krajobrazu kulturowego na pograniczu czesko-niemieckim od roku 1918 do współczesności na przykładzie gminy Dolní Žandov", obronionej w 2016 roku na Wydziale Polonistyki Uniwersytetu Warszawskiego. Rozprawa ta $\mathrm{z}$ pewnymi zmianami została opublikowana $\mathrm{w}$ formie recenzowanej tu książki. Obecnie Doktorka pracuje w Instytucie Slawistyki PAN i jest już autorką kilku interesujących publikacji zamieszczonych $\mathrm{w}$ monografiach wieloautorskich oraz w czasopismach naukowych, a także współredaktorką (wraz z Marcinem Filipowiczem) książki Stowiańska pamięć wydanej w 2017 nakładem wydawnictwa Libron.

Podstawowym materiałem, na którym pracuje Autorka, analizując krajobraz kulturowy gminy Dolní Žandov, są przeprowadzone przez nią wywiady z mieszkańcami gminy, obserwacja terenu oraz pisane źródła historyczne pochodzące $\mathrm{z}$ archiwów. Korzystając z narzędzi metodologicznych dostarczanych przede wszystkim przez studia nad krajobrazem kulturowym (który Autorka czyni najważniejszą osią swoich rozważań) oraz przez studia nad pamięcią, a także posiłkując się innymi dziedzinami humanistyki, Ćwiek-Rogalska prowadzi badania terenowe, sytuując się tym samym w polu etnologii. Książka ta jest jednak przede wszystkim - jak deklaruje Autorka - pracą transdyscyplinarną, w ramach której spotykają się różnorakie dziedziny humanistyki. Ćwiek-Rogalska, analizując krajobraz kulturowy wybranego obszaru, korzysta jednak z ich metodologii nieco wybiórczo. Transdyscyplinarność definiuje ona bowiem jako taką perspektywę badawczą, która zarówno pozwala na wykorzystanie metodologii różnych dziedzin nauki, jak i zwalnia z obowiązku stworzenia jednego, uniwersalnego dla omawianego przypadku narzędzia metodologicznego. Obowiązek taki - jak twierdzi Autorka - charakteryzuje podejście interdyscyplinarne (Ćwiek-Rogalska 14). Ta wygodna pozycja Badaczki budzi niekiedy wątpliwości. $Z$ jednej strony pozwala ona na korzystanie $\mathrm{z}$ teorii oferowanych przez inne dziedziny nauki jak ze słynnej już „skrzynki z narzędziami”, z drugiej strony rodzi szereg niebezpieczeństw, o czym pisała Ewa Domańska (Domańska 50), zwracając uwagę, że podejście takie często prowadzi do wykorzystywania różnych metodologii w sposób narzucający procedurę interpretacji analizowanego materiału i grożący daleko idącymi uproszczeniami. Pisząc o problemie metodologii współczesnej humanistyki, poznańska historyczka podkreślała jednocześnie konieczność prowadzania badań od dołu i budowania teorii i narzędzi interpretacyjnych w oparciu o analizowany materiał. Trzeba przyznać, iż Ćwiek-Rogalska stara się stosować do tych zaleceń. Już na początku książki wprowadza bowiem sformułowanie „miejsca przełamania”, które opisywać ma „miejsca, w których widoczny jest ten interesujący moment, w którym zauważalna jeszcze $\mathrm{w}$ warstwach krajobrazu kultura niemieckojęzyczna styka się ze stosunkowo świeżą warstwą kultury czeskiej" (Ćwiek-Rogalska 13). Miejsca takie, powstałe w efekcie procesów historycznych, naznaczone migracjami, opisywane są w książce. Autorka nie stosuje jednak zbyt często stworzonej przez siebie kategorii i nie wykorzystuje jej ani 
operacyjnie podczas analizy krajobrazu, ani konstrukcyjnie, jako narzędzia porządkującego dalszą narrację. Wydaje się zatem, że potencjał tkwiący w ciekawym pomyśle nie został w pełni wyzyskany. Nieco bardziej szczegółowo do zawiłości metodologicznych powrócę zresztą jeszcze $w$ dalszej części recenzji. Wróćmy jednak do samego tematu pracy.

Zapamiętane w krajobrazie... jest książką, która - jak stwierdza Autorka - opowiada ,o przemianach zachodzących w krajobrazie kulturowym czesko-niemieckiego pogranicza $\mathrm{w}$ regionie historycznym noszącym nazwę pohraničí" (Ćwiek-Rogalska 13). Wyrazu tego Autorka słusznie nie tłumaczy na obecne w języku polskim słowo pogranicze, dostrzegając i starannie analizując odmienny sposób rozumienia i posługiwania się tymi wyrazami w języku czeskim oraz w polszczyźnie. W czeszczyźnie termin pohraničí używany jest, jak zauważa Ćwiek-Rogalska, w kontekście historycznym, a nie geograficznym, ponadto bardziej przypomina polskie wyrażenie „Ziemie Odzyskane", będąc również w tym przypadku narzędziem powojennej propagandy. Zastosowanie polskiego wyrazu pogranicze nie oddawałoby zatem znaczeń, które konotuje czeskie pohraničí (Ćwiek-Rogalska 40). Sposób, w jaki Autorka tłumaczy stosowanie czeskich pojęć, pokazuje zresztą, jak dalece zaznajomiona jest ona nie tylko z językiem czeskim, ale także z polami semantycznymi języka czeskiego, także w kontekście historycznym.

Książka podzielona jest na trzy zasadnicze części. Pierwsza dotyczy metodologii, druga - problematyki pamięci i upamiętnienia, a trzecia warstw krajobrazu kulturowego. Każda z części składa się następnie z (łącznie ośmiu) rozdziałów. I tak: w pierwszej części książki przedstawiono metody prowadzonych badań terenowych i wywiadów, problemy terminologiczne oraz podstawę metodologiczną. Ćwiek-Rogalska opisuje zarówno kluczowe dla swojej pracy źródło - analizowane wywiady, których jest łącznie 39 - jak i sposób obserwowania opisywanego przez siebie obszaru - spacery po okolicy, wykonywane notatki, etc. Osobny podrozdział poświęciła swoim rozmówcom i rozmówczyniom oraz metodologii prowadzenia wywiadów (kwestionariusz pytań, wywiad pogłębiony). Etnolożka w podrozdziale Sytuacja badaczki ujawnia także swoje pochodzenie, zdradzając, że fakt, iż sama wyrosła na polskich "Ziemiach Odzyskanych" pozwolił jej jednocześnie lepiej zrozumieć czeskie pohraničí i sformułować wnioski dotyczące odmienności tych obszarów, a w związku z tym także nietrafności nadużywanej w badaniach analogii (Ćwiek-Rogalska 26-27). Konstatacja ta jest bardzo wartościowa, także w obliczu pokusy traktowania choćby i tylko polskich "Ziem Odzyskanych” jako pewnej homogenicznej całości, której niestety często ulegają polscy badacze czy badaczki. 
Na problem ten słusznie zwraca uwagę Robert Traba postulując myślenie o "Ziemiach Odzyskanych" raczej w kategoriach cząstek, swoistych „archipelagów” (Traba 96-97).

Następny rozdział I części książki traktuje, jak wskazuje sam jego tytuł, o pojęciach. W tym miejscu bohemistka skupia się przede wszystkim na dwóch podstawowych zagadnieniach: krajobrazie i pamięci. Wcześniej jednak formułuje definicję krajobrazu kulturowego. Jest on dla niej „przestrze[nią], w której widoczne są działania człowieka, możliwe w takim stopniu, na jaki pozwalają warunki naturalne. Działania ludzkie rozumiem tu jednak także [pisze Ćwiek-Rogalska - M.P.] jako niematerialne elementy, takie jak wspomnienia i narracje opowiadające o tymże krajobrazie" (Ćwiek-Rogalska 30). Podczas gdy drugie zdanie tej definicji jest nie tylko zrozumiałe, ale także zwyczajnie mądre i świadczące o szerokim horyzoncie Badaczki, pierwsze zdanie definicji wprowadza jednak konfuzję. Co oznacza bowiem stwierdzenie, że krajobraz kulturowy jest przestrzenią, w której widoczne są działania człowieka ograniczone warunkami naturalnymi? Czy Autorka sugeruje wzajemność działań natury i działań człowieka? A więc czy traktuje naturalne środowisko jako sprawcze? Czy jednak krajobraz kulturowy odnosi się przede wszystkim do aktywności ludzkiej jedynie w granicach stworzonych przez naturę? Brak tu wyjaśnienia odnoszącego się do sposobu rozumienia roli i postrzegania natury, która w samej książce jest paradoksalnie bardzo słabo reprezentowana. Autorka skupia się na prezentacji dziedzictwa kulturowego, a to, że jest ono osadzone w krajobrazie przyrodniczym, umyka jej być może nazbyt często. Natura pojawia się w analizach Ćwiek-Rogalskiej raczej jako tło, ewentualnie znak nieobecnego, ale nie jako aktywny aktor. Taki sposób ujęcia krajobrazu ukazuje sprzeczność w sposobie jego objaśniania. $Z$ jednej strony pisze ona, że „[m]ieszkańcy miejscowości [...] zmieniali się, czy to z przyczyn naturalnych, czy motywowanych politycznie, natomiast krajobraz, na który wpłynęli - trwał”. Dalej zauważa jednak, że „nie jest on jednak bierną sceną, na której rozgrywają się wydarzenia. Dzięki swoim właściwościom [pytam: jakim? Co Autorka ma na myśli? - M.P.] może je wywoływać, ale także przywoływać, kiedy mieszkańcy zaczynają go wspominać" (Ćwiek-Rogalska 15). To ta druga perspektywa, nie tyle trwania krajobrazu rozumianego bardziej jako rama (rodem z Braudelowskiego Morza Śródziemnego), ale właśnie jego zmienności i sprawczości wydaje się być Badaczce bliższa. Potwierdza to jeszcze raz na kartach książki, tym razem słusznie przywołując Tima Ingolda (Ćwiek-Rogalska 35). Ćwiek-Rogalska jest zatem świadoma istnienia koncepcji zakładających sprawczość natury i wzajemność oddziaływania czynników naturalnych i ludzi, nie wykorzystuje jednak potencjału tkwiącego w takiej perspektywie. Perspektywie, która - dodajmy także - istotna jest dla historii środowiskowej (o badaniach mieszczących się w nurcie posthumanistyki nie wspominając). Nie oczekuję rzecz jasna od Autorki, by narzuciła sobie taką czy inną badawczą optykę, ale by wyraźnie zadeklarowała, czy zamierza czynić z owej wzajemności i dynamiczności krajobrazu w jego natu- 
ralnym wymiarze istotny przedmiot swoich rozważań, czy też nie. Zapowiedź taka tkwi bowiem we wstępnych rozważaniach teoretycznych nad zagadnieniem krajobrazu, potem jednak nie jest realizowana podczas analiz konkretnych przypadków. Mimo że Badaczka sprawnie porusza się na polu teoretycznym przywoływanych tu, kluczowych dla pracy pojęć, problem wzajemnego uwikłania kultury i natury w podrozdziale zatytułowanym Krajobraz... (tutaj bez uzupełnienia: „kulturowy”) jest potraktowany pobieżnie, zaś rozdział nie ukazuje, w jaki sposób Autorka będzie się dalej odnosić do owego uwikłania.

Drugie istotne miejsce rozważań dotyczących pojęć zajmuje kategoria pamięci. Najważniejszym punktem odniesienia w tym obszarze Autorka czyni koncepcje Jana i Aleidy Assmannów. Ponadto za inspirujące uznaje przede wszystkim koncepcję postpamięci Marianne Hirsch oraz klasyczną pracę Maurice'a Halbwachsa poświęconą społecznym ramom pamięci. Wszystkie te teoretyczne ujęcia są $\mathrm{w}$ niewielkim stopniu obecne $\mathrm{w}$ analizie konkretnych przypadków. Obserwując siatkę teoretycznych odniesień do problematyki pamięci, można z jednej strony dostrzec dużą łatwość poruszania się Autorki na tym polu, z drugiej zaś nieco zbyt daleko posuniętą powściągliwość $\mathrm{w}$ korzystaniu $\mathrm{z}$ niezwykle bogatej literatury dotyczącej kwestii pamięci. Wprawdzie Ćwiek-Rogalska przywołuje prace wspomnianych wyżej badaczy, jednak kontekst jej wiedzy na podejmowany tu temat buduje w dużej mierze jedno opracowanie: Modi memorandi. Leksykon kultury pamięci (2014). Zaskakuje także brak odniesienia do koncepcji miejsc pamięci Pierre'a Nory. Francuski badacz pojawia się na kartach recenzowanej książki tylko raz, dopiero na stronie 168 i to za pośrednictwem Kornelii Kończal. Nie uważam oczywiście, że czerpanie z koncepcji Nory jest obligatoryjne, tym bardziej że, choć niezwykle swego czasu inspirująca, doczekała się już ona obszernej krytycznej bibliografii, jednak w części referującej stan badań nad pamięcią, także właśnie w kontekście osadzenia w krajobrazie kulturowym, jej nieobecność jest wyraźnie dostrzegalna. Ponadto wydaje się, że w przypadku analizowanych w książce zjawisk kulturowych akurat koncepcja Nory dobrze ilustruje rozważane kwestie, co nasuwa się w szczególności w wypadku historii doktora/doktorów i uzdrowiskowości. Propozycja teoretyczna Nory, odnosząca się właśnie do pracy pamięci zbiorowości, gdzie miejsce pamięci rozumiane jest nie tylko jako fizycznie istniejące, ale rozszerzone jest także na symbole i postaci, zdaje się dobrze korespondować z prezentowanymi przez Autorkę analizami (Nora).

Część drugą porządkuje układ chronologiczny, który Badaczka zastosowała w sposób bardzo przekonujący, nie ulegając klasycznym funkcjonującym podziałom. Jest to szczególnie widoczne $\mathrm{w}$ nietypowym $\mathrm{z}$ punktu widzenia tradycyjnej chronologii wyróżnieniu okresu okołowojennego, który Autorka zamyka w dekadzie 1938-1948. Standardowe wskazywanie na 1945 jako na czas przełomu w wypadku mikroujęć prowadzi często do niepotrzebnych uproszczeń, których Autorce udało się uniknąć. 
Wracając jednak do początku owej części należy zauważyć, że w pierwszym jej rozdziale Autorka, omawiając okres 1918-1938, koncentruje się na dwóch podstawowych przykładach - pomnika ku czci poległych w I wojnie światowej oraz szkoły czeskiej i niemieckiego przedszkola. Bohemistka rozważa tu kwestię konfliktu zachodzącego w warstwie językowej w związku z krajobrazem kulturowym omawianej gminy. Słusznie zauważa, że język jest „jednym z kryteriów różnicujących elementy krajobrazu kulturowego i rzutuje na ich postrzeganie" (Ćwiek-Rogalska 47). Ważną rolę w rozważaniach odgrywają także kwestie narodowościowe. Szczegółowo, posiłkując się także źródłami pozyskanymi z archiwów, Ćwiek-Rogalska przygląda się omawianym tu problemom, a więc również konfliktom wokół pomników.

W następnym rozdziale tej części Autorka opisuje przechodzenie gminy Dolní Žandov z rąk czeskich do niemieckich i z powrotem w latach 1938-1948. Swe rozważania toczy wokół zagadnienia sposobu rozumienia własności i stanu prawnego dotyczącego posiadania mienia przez mieszkańców gminy, nie uciekając także od trudnego tematu mienia należącego do Żydów. W ostatnim rozdziale tej części poświęconym gminie Dolní Žandov w latach 1948-2014 podejmuje ona problematykę dotyczącą państwowych gospodarstw rolnych oraz znaczenia granic.

Omawiając tę część, nieco więcej uwagi chciałabym poświęcić rozważaniom Autorki dotyczącym „afery pomnikowej” opisywanej w pierwszym jej rozdziale. Bohaterem narracji jest pomnik Józefa II, który został zdewastowany przez legionistów czeskich. Był to odwet, jakiego dokonała ludność czeska w odpowiedzi na niezgodę rekrutów niemieckich na powoływanie ich do armii czechosłowackiej w 1920 roku. Po zdewastowaniu pomnika w listopadzie tego roku Niemcy zaczęli rozprawiać się z miejscami i symbolami czechosłowackimi. Ofiarą padła między innymi czeska szkoła. Zrekonstruowana przez Autorkę historia, która opowiada o prawdopodobnych konsekwencjach owych wydarzeń, jest nie tylko interesująca sama w sobie, ale także przekazana w sposób ciekawy i przekonujący. Badaczka, analizując "aferę pomnikową", trafnie oddaje zawiłości czesko-niemieckich relacji na omawianym obszarze, za przykład wybierając opowieść o miejscach pamięci. Pewne wątpliwości budzi jednak sama interpretacja aktu niszczenia takich symboli, jakimi były pomniki.

Autorka zbyt mocno w mojej opinii wydarzenia zachodzące na pohraničí wiąże ze specyfiką miejsca czy regionu. Niszczenie pomników jest bowiem spektaklem uniwersalnym, praktykowanym przy okazji wszelkich zmian politycznych, które dokonują się na mapie politycznej świata. Sięgnąć warto zatem po analizy badaczy pokazujących mechanizmy takich praktyk (m.in. Bevan; Doss; Koshar; Michalski i wielu innych), które pozwalają zinterpretować zaistniałe tu wydarzenia w perspektywie bardziej ogólnej, a nie wyrastającej ze specyfiki opisywanego obszaru. Istotną rolę odgrywają tu badania nad zbiorowym afektem przywoływane w związku z analizami upamiętnień i pokazujące, jak akty takie umożliwiają rozładowanie 
zbiorowych emocji (np. Doss 325; Grzesiuk-Olszewska 36; Praczyk 151-165). Takie spojrzenie umożliwiłoby przeniesienie analizowanego przypadku na taki poziom, który pokazywałby dobitnie, że zachodzące w opisywanej gminie zdarzenia stanowią $\mathrm{w}$ tym wypadku przykład uniwersalnych zjawisk. Poruszanie się pomiędzy poziomami tego, co szczególne, oraz tego, co ogólne, nadaje pracom, które mają charakter case study (takim case study jest w tym wypadku badana gmina), głębszy wymiar. Wskazywanie na obie te płaszczyzny pozwala wydobyć to, co dla badanego przypadku jest rzeczywiście wyjątkowe, $\mathrm{i}$ to, co wpisuje się $\mathrm{w}$ procesy typowe dla danych zagadnień. Wówczas wnioski są porównywalne z tymi, które osiąga się przede wszystkim w badaniach komparatystycznych. Pryzmat ten narzuca się zresztą Autorce samoistnie wówczas, gdy wskazuje ona bardzo trafnie na różnice między pohraničí a "Ziemiami Odzyskanymi”, uwydatniając to, co dla analizowanego przez nią przypadku jest wyjątkowe. Wydaje się, że rozważania nad sporem wokół symboli czeskich i niemieckich świetnie służą ukazaniu tego, że zjawiska zachodzące na przysłowiowym „końcu świata” stanowią odbicie tendencji dostrzeganych w bardzo wielu innych miejscach.

W kontekście aktu niszczenia monumentów nie do końca przekonująca wydaje się też interpretacja tego, dlaczego nie został zniszczony pomnik upamiętniający poległych w wojnie prusko-austriackiej 1866 roku. Znamy przypadki, w których pomniki upamiętniające owe wydarzenia upadały właśnie po I wojnie światowej. Stało się tak na przykład w Poznaniu w 1919 roku (Praczyk 151). Skoro przyczyny tej nie udaje się wyinterpretować ze źródeł, być może lepiej byłoby pozostawić pytanie o powód bez odpowiedzi. Inaczej uczyniła Autorka (Ćwiek-Rogalska 54). Z kolei pisząc o pomnikach upamiętniających żołnierzy w I wojnie światowej, traktuje ona fenomen powszechnego stawiania pomników jako specyficzny dla terytoriów Europy Środkowo-Wschodniej i obszaru niemieckojęzycznego (Ćwiek-Rogalska 55). Tu znowu wydaje się, że taka kontekstualizacja jest zbyt wąska. Warto przecież pamiętać, że tego typu pomniki powstawały właściwie wszędzie tam, gdzie masowymi ofiarami stawali się żołnierze ginący w Wielkiej Wojnie. Ta charakterystyczna przemiana sposobu upamiętniania ofiar wojny, która nastąpiła właśnie po I wojnie światowej, z jednej strony wpisuje się w kolejną fazę, jaką przeszła zrodzona w XIX stuleciu statuomania, o której w swym klasycznym już artykule pisał Maurice Agulhon (Agulhon), z drugiej strony dotyka problemu wynikającego z wyjątkowego dla tej wojny doświadczenia powszechności jej skutków i przemian mentalnych, które w jej wyniku zaszły.

Kolejną kwestią, na którą warto zwrócić uwagę przy tej okazji, jest wpisanie omawianego problemu w studia nad rzeczami. Autorka, śledząc dalsze losy pomników czy ich pozostałości, bardzo trafnie odnosi się do ich materialności, znaczenia samego budulca i symbolicznych funkcji, jakie może on pełnić. Studia nad rzeczami są jednym z ważniejszych dla Badaczki punktów odniesienia, o których pisze już w części metodologicznej (Ćwiek-Rogalska 34-35). W czasie prowadzonych ana- 
liz umiejętnie wraca ona do przywoływanych przez siebie koncepcji badawczych, a szczególnie często do książki pt. Rzeczy i Zagłada Bożeny Shallcross (Shallcross). Książka ta służy zresztą Ćwiek-Rogalskiej za ważny punkt odniesienia, którym posiłkuje się, interpretując także inne omawiane zjawiska, choć szkoda, że w stopniu dużo skromniejszym czyni to w odniesieniu do innych badaczy i badaczek, których wskazuje w teoretycznym wstępie. Aktywna rola przedmiotów i ich sprawczość, ujawniająca się wielokrotnie w omawianej książce, każe jednak postawić pytanie, dlaczego Autorka nie wspomina w ogóle o Bruno Latourze - francuskim badaczu, będącym jedną z kluczowych postaci fundujących obecne we współczesnej humanistyce myślenie o aktywnej roli rzeczy w świecie. I znów, nie twierdzę, że Autorka powinna $\mathrm{z}$ jego koncepcji korzystać (decyzje takie pozostają niekwestionowanym prawem autorów i autorek wszelakich rozważań naukowych), wydaje się jednak, że referując i pisząc o obszarze badawczym, jakim są studia nad rzeczami (Ćwiek-Rogalska 34-35), pominięcie tego badacza tworzy nieusprawiedliwioną lukę.

Pragnę jednak podkreślić, że mimo wątpliwości, które nasuwają się mi przy lekturze tej części pracy, rozdział poświęcony okresowi 1918-1939 pokazuje, że Autorka bardzo sprawnie porusza się nie tylko po samym analizowanym terenie i krajobrazie kulturowym regionu, ale także jest dobrze zaznajomiona $\mathrm{z}$ jego historią. Owa historyczna perspektywa, uzupełniająca późniejsze badania etnologiczne, pozwala jej o wiele pełniej zrozumieć to, co (i jak) w krajobrazie zostaje zapamiętane. Przyjęcie tak rozległej perspektywy czasowej, umiejętne korzystanie ze źródeł historycznych pozyskanych $\mathrm{z}$ archiwów, nieczęste w badaniach etnologicznych, stanowi ogromny walor pracy i stanowi o jej wyjątkowości.

Część trzecia książki, Warstwy krajobrazu kulturowego, rozpoczyna się rozdziałem poświęconym tematyce ruin. Podjęcie tego wątku wynika nie tylko z obserwacji poczynionych przez Ćwiek-Rogalską w terenie, ale także z faktu, że przywołują je również często jej rozmówcy. Jest to, dla prezentowanej książki, zagadnienie wielkiej wagi, gdyż - jak zauważa Autorka - „[p]roblem ten jest jednym z kluczowych elementów pozwalających zrozumieć specyfikę krajobrazu kulturowego pohraničí i zmian, jakie dokonały się w nim na przestrzeni lat" (Ćwiek-Rogalska 129). Omawia ona ruiny w kontekście nawarstwień tworzących się na przestrzeni całego stulecia, ciągle obecnych bądź jako ślad tego, co było, bądź jako wspomnienie, zatarte już w krajobrazie. Kolejny rozdział tej części dotyczy miejsc kultu religijnego (nie zawsze jednak pełniących tę funkcję po dziś dzień). Autorka opisuje tu kaplicę Kneipelbach, cmentarze oraz kościół. Rozdział ten, zatytułowany Sacrum. Lokalne i globalne interpretacje $\mathrm{w}$ sposób bardzo interesujący ukazuje wieloznaczny wymiar przywoływanych miejsc oraz to, jak w jednym obiekcie mogą splatać się bardzo różne znaczenia (od religijnych przez narodowościowe, po estetyczne). Autorka zauważa na przykład trafnie, że 
[h]istoria krajobrazu kulturowego staje się tu równocześnie historią traumy. Krajobraz jest bowiem traumatyczny nie sam w sobie, ale dopiero wtedy, kiedy się te traumę w nim zobaczy - przez opowiadaną historię, [...] że kaplicę niszczono i okradano jako „niemiecką" (Ćwiek-Rogalska 152).

Spostrzeżenia zawarte w tym rozdziale są bardzo przekonujące i umykają zarzutowi, który sformułowałam, analizując fragmenty poświęcone pomnikom. Autorka przemieszcza się kompetentnie między płaszczyznami tego, co partykularne, i tego, co uniwersalne, na co zresztą sama wyraźnie wskazuje już choćby w tytule tego rozdziału.

Ostatni rozdział tej części i zarazem książki traktuje o Žandovie w kontekście jego uzdrowiskowości oraz o figurze doktora, stanowiącej swoiste miejsce pamięci žandovian. Ten błyskotliwy rozdział w największym stopniu odrywa się od fizycznej przestrzeni, by zakorzenić się przede wszystkim w przestrzeni pamięci. Ważną rolę odgrywa tu kwestia położenia gminy w regionie uzdrowiskowym, o czym świadczą konkretne miejsca, a także nagrobek czy dom doktora Hackenberga. Miejsca te nierozerwalnie związane są ze specyficzną legendą, którą owiane są dwie postaci, zlewające się mieszkańcom gminy w jedną figurę uzdrowiskowego doktora (chodzi o doktora Bachtroga oraz doktora Hackenberga). Wprowadzenie do książki ich historii świetnie pokazuje, jak szerokie może być usytuowanie krajobrazu w pamięci. Autorka, opisując tę historię, potrafiła dostrzec w krajobrazie to, co nierzadko pomijane jest właśnie ze względu na swoje niewystarczająco wyraźne zakorzenienie w fizyczności miejsca. Ćwiek-Rogalska podkreśla ten fakt, celnie zauważając, że:

krajobraz „buduje się" nie tylko na podstawie materialnie obecnych lub pamiętanych miejsc, ale formę może mu nadawać także pamięć o konkretnym człowieku. Dom doktora Hackenberga jest właśnie jego domem, dzięki temu zostaje wydobyty z masy innych žandowskich domów, co więcej, stanowi ważny punkt odniesienia czy wręcz punkt orientacyjny, wokół którego ogniskuje się opisywany przez mieszkańców krajobraz (Ćwiek-Rogalska 189).

Szkoda tylko, że zachodzące tu zjawisko przywodzi Autorce na myśl jedynie konstatacje Caroline Humphrey (Humphrey), a już nie, co sygnalizowałam wcześniej, koncepcję Nory.

Z przywoływanych w tej części książki problemów pozwolę sobie wrócić jeszcze do tematyki związanej z ruinami i poświęcić jej nieco więcej uwagi. Dokonywana przez Badaczkę analiza pojęcia ruin i zwrócenie uwagi na ich funkcję w kontekście rozciągnięcia tego zjawiska w czasie i kwestii pamięci jest godne docenienia. Ćwiek-Rogalska pisze na przykład (co warto przywołać, bo kolejny raz ujawnia się tu szerokie i otwarte spojrzenie na problem badawczy, które prezentuje Autorka), że definiuje ruinę także jako 
budynki i miejsca nieistniejące, a zapamiętane już jako zniszczone lub niszczejące, których ślady przetrwały zarówno w pamięci rozmówców, jak i w terenie - a nie tylko dla tych, którzy umieją je odszukać, czyli przede wszystkim dla osób, które je pamiętają (Ćwiek-Rogalska 130).

Wskazywane tu przecięcie pamięci i krajobrazu, które dokonuje się na żywym organizmie ludzi, stanowi wartościową konstatację. W sposób wartościowy przeplatają się tu ślady materialne z ich brakiem, wyrytym jedynie w pamięci: „ruina jak pisze Autorka - pozostająca w pamięci staje się stałą komponentą wsi - coś czego nie ma, jest równie wyrazistym elementem krajobrazu jak to, co istnieje. Jedno i drugie można zatem uznać za charakterystyczne dla pohraničí" (Ćwiek-Rogalska 137). Pytam przy okazji po raz kolejny o to, dlaczego charakterystyczne jedynie dla pohraničí, a nie dla tego typu obszarów w ogóle? Tu na przykład wypadające tym razem pozytywnie porównanie do polskich "Ziem Odzyskanych" narzuca się samo.

W prezentowanych analizach dostrzegalny jest jednak brak tego, co wydaje się ważne w kontekście trwania i życia ruin. Nawet traktując o ruinach w perspektywie ich długofalowego rozkładu, pisząc o demolicji, Autorka zapomina, a może świadomie nie przywołuje - a jeśli tak, to dlaczego? - samego „życia” ruin, roli przyrody oraz degradującej się materii. Zdejmuje więc tym samym z krajobrazu niezwykle ważną warstwę, mianowicie tę, która dotyczy samej natury. Przyroda pojawia się jako ślad, ale już nie jako wartościowa i aktywna sama w sobie. Bardzo przydatne są tu koncepcje związane z badaniem procesu (a przecież Autorka dostrzega procesualność zjawisk dotyczących ruin) rujnacji (np. Stoler; Navaro-Yashin). Niedowartościowanie znaczenia środowiskowej warstwy krajobrazu wydaje mi się ważnym zaniechaniem tej części pracy. Wchłanianie dziedzictwa kulturowego przez przyrodę pozwala bowiem rozwinąć ważny namysł nad sprawczością naturalnych walorów krajobrazu, które są przecież tak istotną składową badań nad krajobrazem. W brakującej tu perspektywie ujawnia się przecież nie tylko niestabilna i dynamiczna rola ruin (tego amalgamatu kultury-natury), ale właśnie ich relacyjność, ich współgranie z pamięcią i śladami kulturowego dziedzictwa.

Niedocenienie przez Autorkę znaczenia krajobrazu w jego naturalnym wymiarze wydaje mi się najważniejszą wadą nie tylko wspomnianego powyżej rozdziału, ale w ogóle książki. Prowadzone ostatnio, również na polskim gruncie, coraz świadomiej badania nad znaczeniem przyrody w dziejach i jej relacyjnością, którymi zajmuje się przede wszystkim historia środowiskowa, mogą wnosić, choćby i pomocniczo, bardzo istotny wkład w badania humanistyczne, a tym bardziej w te prowadzone nad krajobrazem kulturowym. Sprzężenie przyrody i kultury w odczytywaniu krajobrazu akcentuje wyraźnie choćby Olaf Kühne (Kühne 38-42). Dość marginalne w książce Ćwiek-Rogalskiej przyglądanie się przyrodzie pozostawia więc niestety pewne uczucie niedosytu, w szczególności właśnie w rozdziale poświęconym de facto rujnacji. 
Przy wszystkich tych sformułowanych wyżej zastrzeżeniach pragnę jednak podkreślić, że książka Ćwiek-Rogalskiej jest pozycją wartościową i interesującą. Mimo niekiedy być może nieco skromnego tła teoretycznego Autorka niewątpliwie jest Badaczką o wysokiej świadomości metodologicznej. Ponadto wykorzystuje szeroki wachlarz źródeł: wywiady z mieszkańcami regionu, archiwalia, materialne świadectwa, które dostrzega w terenie, ikonografię (fotografie) - co pozwala jej na skonstruowanie wielowymiarowego obrazu omawianego obszaru na przestrzeni całego stulecia. Jej badania stają się dzięki temu, jak trafnie sama zauważa w zakończeniu, „nie tylko badaniami pogranicza, ale też badaniami z pogranicza” (Ćwiek-Rogalska 195). Prowadzenie takich badań jest rzecz jasna trudniejsze i naraża zawsze na zarzuty reprezentantów różnych dyscyplin nauki. Są one jednak bardzo wartościowe. Mimo więc ostrza krytyki, na które Autorka zawsze będzie się skazywać, lokując się $\mathrm{w}$ transdysycplinarnej pozycji badawczej, należy takie badania prowadzić. Wymaga to jednak nie tylko rzetelności, której Ćwiek-Rogalska próbuje, niejednokrotnie z sukcesami sprostać, ale też dużej odwagi, której Badaczce, szczęśliwie, nie brakuje.

Na zakończenie pozwolę sobie przywołać ostatnie dwa zdania z książki, które stanowią fragment świetnego podsumowania, a które dobrze oddają temperament Badaczki i mogą, mam nadzieję, zachęcić do lektury:

Wyjeżdżając ze wsi wciąż ma się pod powiekami powidok tego miejsca - znanego tylko ze zdjęć, ale obecnego w postrzeganiu wsi przez przekazane historie. Krajobraz kulturowy utrwala się $\mathrm{w}$ pamięci czasem zupełnie nieoczekiwanie, przypadkiem. A później samochód wchodzi w zakręt i Žandov znika (Ćwiek-Rogalska 195).

A o jakim miejscu mowa, dowiadujemy się już z lektury tej bardzo ciekawej książki.

\section{BIBLIOGRAFIA}

Agulhon, Maurice. „La statuomanie et l'histoire”. Ethnologie francaise 8 (1978). S. 145-172.

Angutek, Dorota. Kulturowe wymiary krajobrazu. Antropologiczne studium recepcji przyrody na prowincji.

Od teorii do empirii. Poznań: Bogucki Wydawnictwo Naukowe, 2013.

Bevan, Robert. The Destruction of Memory. Architecture at War. London: Reaktion Books, 2006.

Domańska, Ewa. „Jakiej metodologii potrzebuje współczesna humanistyka?”. Teksty drugie 1-2 (2010). S. 45-55.

Doss, Erika. Memorial Mania. Public Feeling in America. Chicago-London: The University of Chicago Press, 2010.

Frydryczak, Beata. Od estetyki the picturesque do doświadczenia topograficznego. Poznań: Poznańskie Towarzystwo Przyjaciół Nauk, 2013. 


\section{MAEGORZATA PRACZYK, O STUDIACH KULTUROWYCH NAD KRAJOBRAZEM...}

Grzesiuk-Olszewska, Irena. Polska rzeźba pomnikowa w latach 1945-1995. Warszawa: Wydawnictwo Neriton, 1995.

Humphrey, Caroline. "Chiefly and Shamanist Landscape in Mongolia”. The Anthorpology of Landscape. Perspectives on Place and Space. Red. E. Hirsch, M. O'Hanlon. Oxford: Clarendon Press, 1995. S. 135-162.

Koshar, Rudy. From Monuments to Traces. Artifacts of German Memory. 1870-1990. Berkeley-Los AngelesLondon: University of California Press, 2000.

Kühne, Olaf. „Przestrzeń, krajobraz i krajobraz kulturowy. Terminologia, definicje”. Przeł. Monika Satizabal Niemeyer. Krajobrazy kulturowe. Sposoby konstruowania i narracje. Red. R. Traba, V. Julkowska, T. Stryjakiewicz. Warszawa-Berlin: Wydawnictwo Neriton - CBH PAN, 2017. S. 25-45.

Michalski, Sergiusz. Public Monuments. Art in Political Bondage 1870-1997. London: Rekation Books, 1998.

Navaro-Yashin, Yael. „Affective spacer, melancholic objects: ruination and the production of anthropological knowledge". Journal of the Royal Anthropological Institute 15 (2009). S. 1-18.

Nora, Pierre. Les Lieux de mémoire. T. 1. Paris: Éditions Gallimard, 1984.

Praczyk, Małgorzata. Materia pomnika. Studium porównawcze na przykładzie monumentów w Poznaniu i Strasburgu w XIX i XX wieku. Poznań: Instytut Historii UAM, 2015.

Shallcross, Bożena. Rzeczy i Zagłada. Kraków: Towarzystwo Autorów i Wydawców Prac Naukowych „Universitas”, 2010.

Stoler, Ann Laura. Imperial Debris. On Ruins and Ruination. Durhan-London: Duke University Press, 2013.

Traba, Robert. „Archipelagi miejsc odzyskiwanych”. Borussia. Kultura - historia - literatura 58 (2016). S. 96-101. 